\title{
Framework of religous intitution contribution in community development: Lesson learned from Tomohon, North Sulawesi
}

\author{
Grace Sumbung ${ }^{1}$, Agus Suman ${ }^{2}$, Kliwon Hidayat ${ }^{3}$, Paulus Kindangen ${ }^{4}$ \\ ${ }^{1}$ Postgraduate Student of Environmental and Development Study, University of Brawijaya, Malang, 65145 East \\ Java, Indonesia and Budi Utomo High School of Economic, Manado, North Sulawesi, Indonesia. \\ ${ }^{2}$ Faculty of Economy, University of Brawijaya, Malang, 65145 East Java, Indonesia. \\ ${ }^{3}$ Faculty of Agriculture, University of Brawijaya, Malang, 65145 East Java, Indonesia \\ ${ }^{4}$ Faculty of Economy, Sam Ratulangi University, Manado, North Sulawesi, Indonesia
}

\begin{abstract}
The study aimed to construct the framework of religious institution in Christians community in Tomohon, North Sulawesi Indonesia. This study shows that the activity of Church as a main religious institution in Tomohon provides significant role in community development. Community empowerment pattern is performed by the church through the establishment of training institution (i.e. BLPT Kaaten, Tomohon), which is actively provides opportunities to increase community skill and knowledge on coconut wood based industry. Such institution also assists in participant training so that the participants can open their own business independently to support daily expenses, education fees, and health costs. Significantly, the Church programs contributes to community health, eeducation, works opportunities and therefore decrease number of jobless and crimes. The programs significantly contributes to community social and economic status.
\end{abstract}

Keywords: Community development, Poverty alleviation, North Sulawesi, SMEs

\section{Introduction}

Religious institution has been known contributes significantly to community development. Throughout the world, religion is one of important social mediator to improve society. Scholars identify the numerous positive contribution of religions institution in community development. It is including the rise of and enhancing community participation in development programs. Community participation and community development are perhaps the crucial points in every discussion related to development. It is particularly important because many communities in developing countries have less attention and participation in development [1] [2]. The less attention and participation in development has been identified as crucial problems and limitation towards sustainability life among community in developing countries. There are formal and structural approaches to increase people participation in development program, but many of the fail in implementation [3]. Introducing and linking spiritual aspect and value of community in development issues led the religious institution become the alternative keys. To be successful and therefore achieve sustainable life of community, the religions institute must be able to deliver spiritual messages to community target. It is particularly effective to be conducted in a strong religion-based community.

Throughout the world, there is growing awareness of sustainable development. This is happening for a number of reasons. The massive development and resources depletion has been reported contribute to the global resources sustainability. Moreover, the social consequences of the natural resources exploitation and unbalance development has been discussed in detail elsewhere. Mainly, it is encompasses increasing number of natural resources depletion and poverty [4]. Social studies of poverty indicate that there are relationship among poverty and development. Poverty and lack of human education is the barrier for development. Directly or indirectly, poverty is the one of the most important factors in nation's development. According to scholar, people must be seen as part of the solution, rather than as part of the problems [5] [6] [7]. In such a case developing and enhancing people capacity through its social aspect (i.e. social organization) is important. It is particularly important when central government facing resources limitation.

Religious institution is increasingly being recognized as one of the potential aspect for poverty reduction and community development. Among them, Church plays an important role in fostering the society[1] [2]. Fostering Church in community development program is one of the significant form of multi-stakeholder contribution to solve complex social problems [8]. The role of church has become one of the empowerment keys in North Sulawesi, Indonesia. Many governmental agency and international institute for development are interested in religions institution as community development instrument, but most of them have minimal knowledge. It is particularly important in developing countries such Indonesia. The study aimed to reveal the role of The Christian Evangelical Church in Minahasa (locally called Gereja Masehi Injili Minahasa, GMIM) in Tomohon which had been successful to put efforts in society empowerment and poverty eradication with a 
great result. The study would contribute the arrangement of religion institution-based empowerment model in Christian society of developing country

\section{Research Methods}

Field work was done in Tomohon City, North Sulawesi Province. The Tomohon City located in the hearth of North Sulawesi Province with the area is c.a. 147, $2178 \mathrm{~km}^{2}$. According to demography data, $75 \%$ of the people in Tomohon are Christians. The majority of local dweller is traditional farmer. Geographically, Tomohon City located at tropical area with 0118 ' 51" north latitude and 124 49" 40 " east longitude. The Tomohon area has hilly topography and is surrounded by active mountains (Fig.1).

The lands in Tomohon have been identified very fertile due to volcanic activity impacts. Farmer cultivated numerous vegetables in highland orchards. Recently, however, farmer cultivate flower as a prospective agriculture commodity. Plantation area found in everywhere with main crops including coconut, clove, vanilla, coffee and Aren palm. Coconut has been cultivated in North Sulawesi province for thousands of years. The biggest production is coconut reaching 484.57 tons in 2011 [9]. The conservation of North Sulawesi's biodiversity is crucial toward sustainable live of society. The challenges for sustainable uses of resources ultimately depend of the human quality improvement [10].

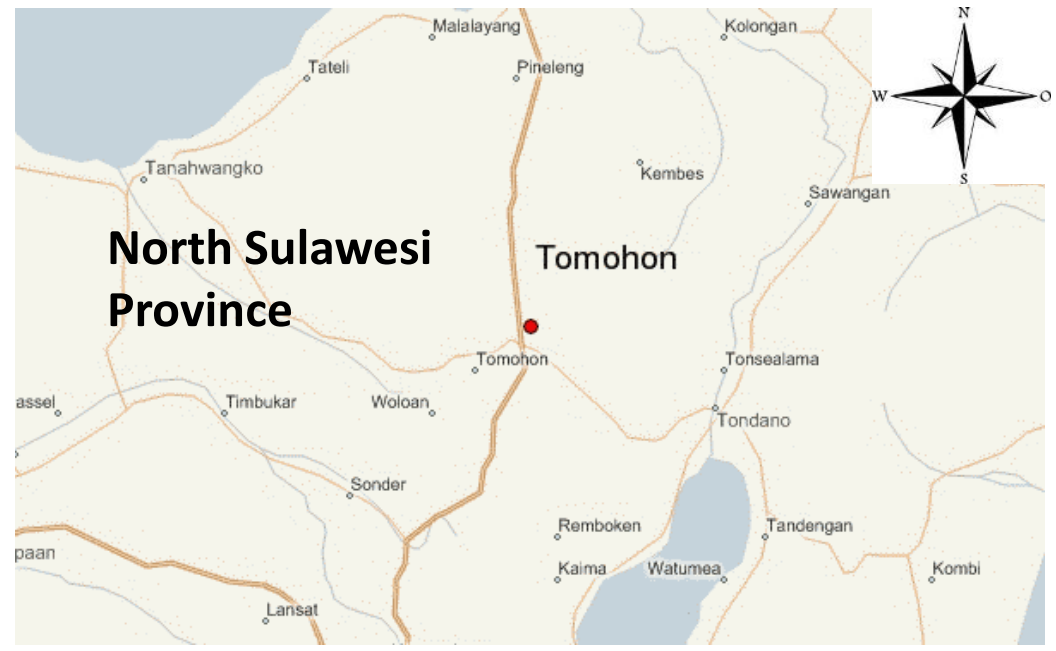

Fig. 1. Geographic position of Tomohon in North Sulawesi Province

Two basic methods in social survey were used, namely in-depth interviews and Focus Group Discussion (FGD). In-depth interviews was started by identifying key question that will be delivered to the informant, identifying the key person who are identified able to provide information regarding to the research question, and selecting the proper time and location for in-depth interviews implementations. Through the previous study, the informant for in-depth interviews encompasses Pastor, church leader and people who has information regarding community development program which are conducted by church.

In in-depth interviews, a face to face interviews was done in particular time and space which are setting by informant and researcher as interviewer before. Data and information which are generated during interviews process was recorded using recorder for further analysis. FGD method was applied to generated field data from specific group. The participants of discussion was grouped into some group, namely citizens participating in the activity of training, workers in BLPT, and whole sellers of raw material (coconut wood). The discussion was done and managed by moderator. Several key themes of discussion were delivered by moderator and participant respond was recorded using field notes and recorder. Data and information generated from interviews and group discussion were analyzed descriptively.

\section{Result and Discussion}

\section{Church as a religious institution for community development}

In North Sulawesi, there are numerous body and institutes in community empowerment and development program, and Church is one of the important religious institutions in such programs. The Christian Evangelical Church in Minahasa (GMIM) in Tomohon supervises the area of Minahasa, Manado, and Bitung, North Sulawesi. As a religious organization, GMIM caries several mission elaborations, encompasses 
Evangelism and Education. In order to implement such task, GMIM establishing the religion organization namely Fostering Center for Church Member (PPWG). The head office of organization located at Kaaten Tomohon. According to the informant, there are numerous social and educational activities which were delivered by church-based organization. Religious organization nowadays has been viewed as an alternative for community development instrument in North Sulawesi. This is similar with church in developing and developed countries [11] [12] [13] [14] . In such region, there are numerous report describes the numerous activity as social activity promoted by Church. Poverty status among church member and effort to increase family ability to access education becomes the main issues. As far, there are positive result of the programs which area implemented by Church as a religious organization in local community in developing countries.

Historically, PPWG was established by cooperation between GMIM synod and Church in Netherlands in order to seek the development of fostering center for church member, the congregation. According to informant, the cooperation is important because PPWG has several limitation, encompasses funding, human resources, and equipment. Such limitation was common in developing countries. It has been identified as limitation for development. In developing countries, one of the strategies to minimize the problems is inviting overseas organization to initiate and enhance the activity of local organization. Critics often occur due to independency of organization due to its dependent support from overseas institutions [15] [16].

PPWG's remarkable achievement is appreciated by churches in the area of Central-North Sulawesi and overseas. One of foreign social organizations which provide support is EMS (Evangelische Missionswerk in Sudwestdentcehland). EMS sends engineer and experts to assist teh BKLK activity in Tohomon. Then, they financially support education, equipment, and expenses for instructors. This funding is self-managed at BKLK Kaaten under the direct monitor of representative appointed by EMS. These activity allowing technological tranfers from western to local people. It is principally important for the future community empowerment among congregation and its surrounding society in Tomohon. The role of church in North Sulawesi is not much different with others' role in the world. Its role in society empowerment is primarily initiated in America, Europe, Pacific, and other places as well [14] [17] [18].

\section{The evolution towards SME's Development}

The organizational and its philosophical aspect underlying Church movement in order to develop society welfare result the SMEs as a key component for community development. In developing countries, small and medium enterprises (SMEs) nowadays become the instrument for poverty reduction. SMEs provides opportunities to employ local community with medium skill and therefore provides job for people. This is becomes the programs to reduce poverty in many less developed countries [19]. According to informant, the argument of establishing SMEs ultimately inspired by dream to provides business unit which are able to operate by congregation. There are some improvement in organization and its objectives (Fig.2).

The most crucial step of the movement is creation of BLPT as technical institute to provide numerous vocational education and training. In Indonesia, BLPT is a new model of informal education with the objectives is providing a sequential training for community. It is particularly important when there is limitation to enter formal education. In Tomohon, many congregations were invited to BLPT programs. BLPT provides assistance and advocacy in performing SMEs (Locally called IKM/UKM). The active effort of BLPT to produce numerous goods from coconut wood receives appreciation from society. BLPT is getting more popular nationally and internationally.

The entrepreneurial ability of society assisted by BLPT has inspired some new ideas. One of the emerging ideas was to use palm wood as furniture materials and souvenir. It was motivated by Willie Smith's research on palm wood. The wood is available in the area of Minahasa and around North Sulawesi. At this time, an experiment on using palm wood as furniture and souvenir was started. Thus, there is one more program adding value for BLPT. In such a case, however, network among community member, BLPT and church is important. The network between stakeholders in community development has reported as important key aspect [19].

The evolution of church movement ultimately was affected by increasing available models of community development in some countries which are adopted by parson and church leader in Tomohon. According to informant, increasing knowledge on the opportunities of religious institution in North Sulawesi related to the increasing number of people who graduate from university. Scholars note that there are positive relationship on the education levels and community movement [20]. As shown in Fig. 2. The first era of church is ultimately provides basic roles to society services, namely social activity and evangelism. It is commonly found in Christian community in developing countries. Further development, however, put the strategies issues on the contribution of church in community development. This allow religious institution enlarge and diversify its socio-economical contribution. The new program namely education and community development become crucial. Informal education provided simultaneously by local people training related to numerous skills. In Tomohon, focus mainly addressed to the local people ability to produce numerous goods from coconut woods. 


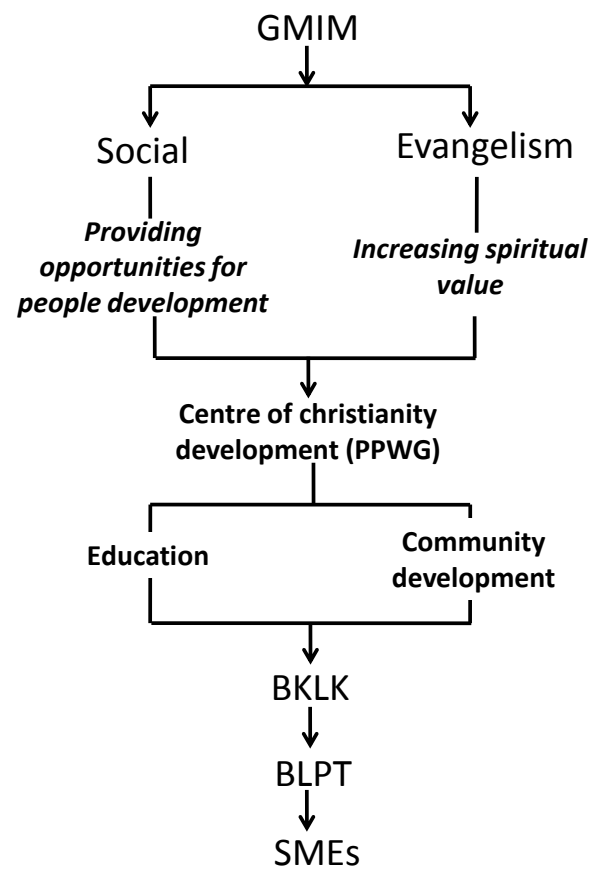

Fig. 2. The contribution of church in community development through SMEs

\section{BLPT and community development}

The contribution of BLPT in community development ultimately related to the effort to improve economy aspect of congregation. According to informant, BLPT programs result significant changes in some life parameter which are related to economical status (Table 1). Through the BLPT program, there are changes in life expectancy, especially health quality; education opportunities, works opportunities, social and economical status. Previously, life expectancy has been viewed as a high cost issues. This aspect only reaches by rich man and there are no opportunities for the poor. The BLPT programs, however, provides opportunities for health improvements. The changes of lives toward better living standard have been stated by informant and this result confirms that the church social programs provide numerous opportunities for community development.

Table 1. Comparative family status related BLPT programs implementation.

\begin{tabular}{|c|c|}
\hline \multicolumn{2}{|c|}{ Life expectancy } \\
\hline $\begin{array}{l}\text { Before } \\
\text { People have health information, but ignored health as a } \\
\text { crucial aspect in human life, poor sanitation management } \\
\text { lead to numerous diseases }\end{array}$ & $\begin{array}{l}\text { After } \\
\text { Increase appreciation in family health and sanitation. }\end{array}$ \\
\hline \multicolumn{2}{|c|}{ Education } \\
\hline $\begin{array}{l}\text { Before } \\
\text { Views Childs education as secondary needs. Education } \\
\text { very expensive; education process very complicated; } \\
\text { education related to urban society, no needs for rural } \\
\text { society. Few students have good access to basic education } \\
\text { due to low parent's appreciation in education. }\end{array}$ & $\begin{array}{l}\text { After } \\
\text { Education very important for future; possibility to access } \\
\text { education (i.e. through scholarships, administrative } \\
\text { assistance). Increase in education accessibility, including } \\
\text { stundent who are drop out from formal education (ie. } \\
\text { Junior and high school). }\end{array}$ \\
\hline \multicolumn{2}{|c|}{ Works opportunities } \\
\hline $\begin{array}{l}\text { Before } \\
\text { Limited, there are need special skill to access god jobs. } \\
\text { Low of entrepreneurial spirits }\end{array}$ & $\begin{array}{l}\text { After } \\
\text { Education, training and community empowerment create } \\
\text { entrepreneur skill to create and develop jobs }\end{array}$ \\
\hline \multicolumn{2}{|c|}{ Number of jobless and crimes } \\
\hline Before & After \\
\hline $\begin{array}{l}\text { High; dominated by young generation; Crimes commonly } \\
\text { found }\end{array}$ & Decreased; people has work \\
\hline \multicolumn{2}{|c|}{ Views of social - economic status } \\
\hline $\begin{array}{l}\text { Before } \\
\text { Difficulties to access credits and loans; poor market } \\
\text { accessibility (i.e. electronics goods, building materials); }\end{array}$ & $\begin{array}{l}\text { After } \\
\text { Working in BLPT increase social status }\end{array}$ \\
\hline
\end{tabular}


Framework of religous intitution contribution in community development: Lesson learned .....

Socially argues poor people without power, no future.

Available jobs are the crucial factor to economic improvement. There are two aspect related to jobs that are able to meets economic improvements. First is available institution to increase people ability to works, and secondly is ability of economic institutional to driven economic activity (SMEs). The relationship of such component to enhance economic improvement was given in Fig. 2.

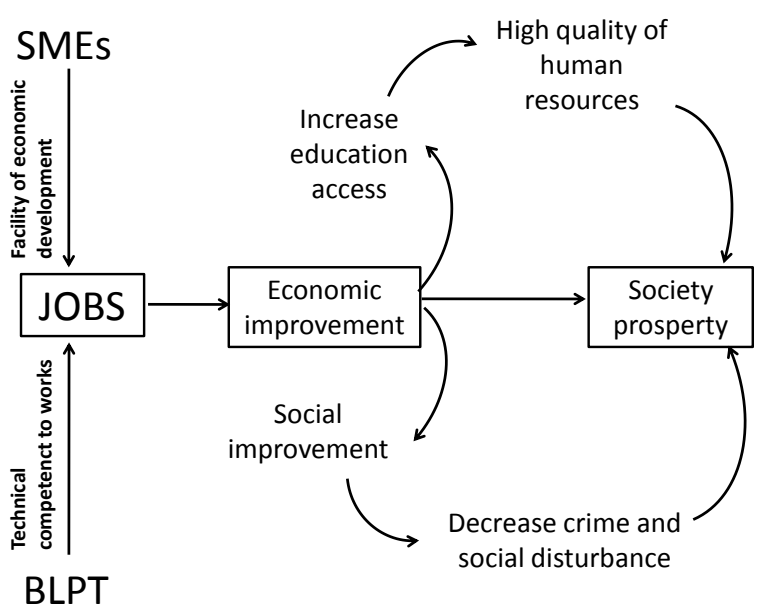

Fig. 2. Framework of community development with society prosperity as outcomes activity

\section{Conclusions}

Community empowerment pattern applied by GMIN via BLPT Kaaten, Tomohon is based on coconut wood processing and has been successful to improve society welfare. In general, the empowerment pattern performed by GMIM is the economic sector. BLPT assists in participant training to start participants' business independently. Thus, it is able to help fulfilling daily living cost, children tuition fee, and health cost, particulary for those who are peasants instead of land owners.

During the business process, BLPT has recruited many labor force from dropout students or those who discontinue their education in lower and higher secondary schools. Hence, it is potential to improve the income of surrounding society, reduce the number of dropout students, improve the development of creative business, lower the number of poverty and unemployment, and increase the income for GMIM's cash.

\section{Acknowledgements}

We are grateful to Prof. Dr. Ir. Soemarno, MS. (Graduate Programs of Brawijaya University), Prof. Dr. Ir. Yogy Sugito (Rector University of Brawijaya), and official staff of Tomohon City for valuable data and informations. We also extent our sincere thanks to Ronal Yusak Boka, Altje Polii, Daysi Sundah, Tressye Turang, Stevia Wowiling for their advice during field survey and data analysis. We would like also to express gratitude and thank respondents, coconut wood purchasers, director and staffs of BLPT, the society around the research area in which we did interviews, and for the research data we obtained about the role of GMIM through BLPT as an effort to improve the society economy. This work supported by Ministry of National Education, Republic of Indonesia.

\section{References}

[1]. C. Candland, Faith as social capital: Religion and community development in Southern Asia, In C. Candland (Ed.) Social Capital as a Policy Resource (Springer, 2001).

[2]. FM. Sewamala and L. Ismayilova, Faith-based institutions as project implementers: An innovative economic empowerment intervention for care and support of AIDS-orphaned and vulnerable children in rural Uganda. Proc. Innovations in Effective Compassion: Compendium of Research Papers for the White House FBO Conference. Washington DC: US Department of Health and Human Services 2008, 213-235.

[3]. C. Tosun, Limits to community participation in the tourism development process in developing countries. Tourism management, 21(6), 2000, 613-633.

[4]. KH. Robèrt, B. Schmidt-Bleek, A.L. Jacqueline,B. George, JL. Jansen, R. Kuehr, P.P. Thomas, M. Suzuki, P. Hawken, and M. Wackernagel. Strategic sustainable development-selection, design and synergies of applied tools. Journal of Cleaner production 10, (3) 2002, 197-214

[5]. P. Kristjanson,F. Place, S. Franzel and PK. Thornton, Assessing research impact on poverty: the importance of farmers' perspectives. Agricultural Systems, 72(1), 2002, 73-92.

[6]. SJ. Scherr, A. White and Kaimowitz, A new agenda for forest conservation and poverty reduction (Forest Trends, Washington DC, 2004). 
[7]. MS. Grindle, Good enough governance: poverty reduction and reform in developing countries. Governance, 17(4), 2004, 525-548.

[8]. K. Bäckstrand, Multi-stakeholder partnerships for sustainable development: rethinking legitimacy, accountability and effectiveness. European Environment, 16(5), 2006, 290-306.

[9]. BPS Tomohon, Tomohon dalam Angka (Badan Pusat Statistik Tomohon, Tomohon Sulawesi Utara, 2012)

[10]. L. Hakim, Soemarno, SK. Hong, Challenges for conserving biodiversity and developing sustainable island tourism in North Sulawesi Province, Indonesia. Journal of Ecology and Field Biology. 35 (2): 2012, 61-71

[11]. T. Moore, The African-American church: A source of empowerment, mutual help, and social change. Prevention in Human Services, 10(1), 1991, 147-167.

[12]. EP. Isaac, T. Guy and T. Valentine, Understanding African American learners' motivations to learn in church-based adult education. Adult Education Quarterly, 52(1), 2001, 23-38.

[13]. L. Simpson, L. Wood and L. Daws, Community capacity building: Starting with people not projects. Community Development Journal, 38(4), 2003, 277-286.

[14]. R. Scheyvens, Church women's groups and the empowerment of women in Solomon Islands. Oceania, 2003, 24-43.

[15]. JCP. Colfer and IAS. Resosudarmo, Which way forward? People, Forest, and Policy making in Indonesia (Research For The Future, Washington, 2002).

[16]. S. Fritzen, Beyond "political will": how institutional context shapes the implementation of anti-corruption policies, Policy and Society, 24(3), 2005, 79-96.

[17]. S. Duthy and B. Bolo-Duthy, Empowering people's organizations in community-based forest management in the Philippines: The community organizing role of NGOs. Annals of Tropical Research, 25(2), 2003, 13-28.

[18]. MK. Campbell, MA. Hudson, K. Resnicow, N. Blakeney, A. Paxton and M. Baskin, Church-based health promotion interventions: evidence and lessons learned. Annu. Rev. Public Health, 28, 2007, 213-234.

[19]. B. Johannisson and A. Nilsson, Community entrepreneurs: networking for local development. Entrepreneurship \& regional development, 1(1), 1989, 3-19.

[20]. M. Coulthard, A. Walker and A. Morgan, People's perceptions of their neighbourhood and community involvement. ( The Stationery Office, 2002). 